\title{
Effect of alteration in organic material of the occlusal caries on DIAGNOdent readings
}

\section{Efeito das alterações no conteúdo orgânico de lesões de cárie oclusal sobre as leituras com DIAGNOdent}

\author{
Fausto Medeiros Mendes* \\ Sérgio Luiz Pinheiro* \\ Antonio Lucindo Bengtson**
}

\begin{abstract}
DIAGNOdent is a laser fluorescence device used for dental caries diagnosis in occlusal and smooth surfaces. Despite the promising preliminary results, the molecules involved in the increase of fluorescence in carious lesions remain unclear. The aim of this study was to compare the laser fluorescence readings before and after changes in the organic material of occlusal carious lesions in primary teeth. Twenty-four primary molars stored in saline solution with at least one site with occlusal caries were divided into two groups. The control group had 17 sites with caries and the experimental one had 16 sites. The carious lesions were measured with laser fluorescence. The experimental samples were then removed from the storage solution and immersed in a $2 \%$ sodium hypochlorite solution for 24 hours. After washing with water, the teeth were measured again with the laser fluorescence device. The teeth of the control group were submitted to the same procedures, but saline solution was used instead of the sodium hypochlorite solution. A statistically significant reduction in the mean of the readings after immersion in the two tested solutions compared with the initial readings was observed in both groups, but the decrease was statistically higher in the experimental group $(\mathrm{p}<0.0001)$. In this study, the data indicate that changes in the fluorescence of carious lesions measured by the laser fluorescence are mainly due to the organic content alterations rather than to the mineral loss.
\end{abstract}

DESCRIPTORS: Occlusal splints; Tooth, deciduous; Fluorescence; Lasers; Dental caries.

\begin{abstract}
RESUMO: DIAGNOdent é um aparelho de fluorescência a laser usado para o diagnóstico de lesões de cárie dentária em superficies oclusais e lisas. Apesar dos resultados preliminares promissores, as moléculas envolvidas no aumento da fluorescência em lesões de cárie permanecem sem explicação. O objetivo deste estudo foi comparar as leituras com o aparelho de fluorescência a laser antes e depois de alterações no conteúdo orgânico de lesões de cárie oclusal em dentes decíduos. Vinte e quatro molares decíduos armazenados em soro físiológico com pelo menos um sítio com lesão de cárie oclusal foram divididos em dois grupos. O grupo controle foi composto de 17 sítios com cárie, e o grupo experimental, 16 sítios. As lesões de cárie foram medidas com o aparelho de fluorescência a laser. As amostras do grupo experimental foram então removidas da solução de armazenamento e imersas em uma solução de hipoclorito de sódio a $2 \%$ por 24 horas. Depois da lavagem com água, os dentes foram medidos novamente com o aparelho de fluorescência a laser. Os dentes do grupo controle foram submetidos aos mesmos procedimentos, mas soro fisiológico foi usado em vez de hipoclorito de sódio. Uma redução estatisticamente significante na média das leituras depois da imersão nas duas soluções testadas comparadas às primeiras leituras de ambos os grupos foi observada, mas a porcentagem de redução foi estatisticamente maior no grupo experimental $(\mathrm{p}<0,0001)$. Neste estudo, os dados indicam que alterações na fluorescência de lesões de cárie medidas pelo aparelho de fluorescência a laser ocorrem principalmente devido a alterações no conteúdo orgânico ao invés da perda mineral.

DESCRITORES: Placas oclusais; Dente decíduo; Fluorescência; Lasers; Cárie dentária.
\end{abstract}

\section{INTRODUCTION}

Dental caries is a multifactorial disease that involves hard tissues of the teeth. Early detection of the carious process allows arrestment of the lesion $^{21}$. Many methods have been devised to provide early detection and quantification of carious lesions ${ }^{1}$. A laser fluorescence ( $\mathrm{LF}$ ) device using a diode laser $(\lambda=655 \mathrm{~nm})$ was developed with the name DIAGNOdent ${ }^{5}$.

Several in vitro ${ }^{2,3,8,9,17}$ and in vivo $0^{10,13,14}$ studies with LF have shown promising results. However, the molecules involved in the increase of fluorescence in carious tissue are not clear ${ }^{15}$. Another

\footnotetext{
*Assistant Professors; ${ }^{* *}$ Chairman and Professor - Discipline of Pediatric Dentistry, Metropolitan University of Santos.
} 
Mendes FM, Pinheiro SL, Bengtson AL. Effect of alteration in organic material of the occlusal caries on DIAGNOdent readings.

Braz Oral Res 2004;18(2):141-4.

quantitative laser-induced fluorescence method (QLF), with an argon-ion laser $(\lambda=488 \mathrm{~nm})$, measures intrinsic fluorescence from the teeth ${ }^{4}$. Nevertheless, studies have demonstrated that LF is fundamentally different from the QLF method ${ }^{18,20}$. QLF results have shown a better correlation with mineral loss in enamel carious lesions than LF measurements ${ }^{15}$. Basic research regarding QLF methods cannot be extrapolated to $\mathrm{LF}^{20}$. Probably, the LF device reflects organic changes in carious lesions rather than mineral loss ${ }^{11,15,16,20}$.

For these reasons, the aim of this in vitro study was to compare LF readings before and after changes in the organic content of occlusal carious lesions in primary teeth.

\section{MATERIALS AND METHODS}

\section{Sample selection}

The protocol of this investigation was approved by the Ethics Committee of the Metropolitan University of Santos. Twenty-four primary molars, extracted for orthodontic reasons, were selected. A written consent was obtained from the adults responsible for the children that donated the teeth. All teeth had at least one site with occlusal caries. Specimens were stored in isotonic $\mathrm{NaCl}$ solution (Labsynth Ltda., Diadema, Brazil) for up to three months. The samples were randomly divided into two groups. Control group had 17 carious sites while the experimental group had 16 sites.

\section{Measurements with laser fluorescence and storage experiments}

One operator performed the LF (DIAGNOdent, $\mathrm{KaVo}$, Biberach, Germany) readings following the manufacturer's instructions. We selected a probe tip A (for occlusal surfaces), calibrated the laser device against a porcelain reference object prior to examination, and then recalibrated it after every tenth reading. Samples were removed from the storage solution, and fluorescence of a sound smooth surface was measured to provide a baseline value for each tooth. Then, the occlusal surface was dried with compressed air for 8 seconds, and readings were performed. Three measurements in each carious lesion were performed, and the mean value was calculated.

After initial readings of each tooth, samples of the experimental group were removed from the saline solution and immersed for 24 hours in a $2 \%$ sodium hypochlorite solution (Labsynth Ltda.,
Diadema, Brazil). The hypochlorite ion $\left(\mathrm{ClO}^{-}\right)$is a nonspecific proteolytic agent ${ }^{12}$. The solution was renewed at every eight hours. After this immersion, occlusal carious lesions were washed for one minute with water deriving from a 3-in-1 syringe, and samples were reimmersed in the isotonic saline solution.

Teeth of the control group were submitted to the same procedures described for the experimental group samples, but an $\mathrm{NaCl}$ isotonic solution was used instead of the sodium hypochlorite solution. Subsequently, teeth were remeasured with the LF device under identical conditions of the first readings.

\section{Statistical analysis}

The paired Student's $t$-test was applied to compare initial and final LF readings in the same groups. The percentage reduction between the final and initial LF readings was calculated in both experimental and control groups. The means of these percentages were compared with the Student's $t$-test. The level of significance was taken as $\mathrm{p}<0.05$.

\section{RESULTS}

Initial readings were compared with readings after the experiment within the same group. A statistically significant reduction in the mean of the readings was observed in both groups after immersion in the solutions (sodium hypochlorite in the experimental group and saline solution in the control group) (Graph 1).

The mean of the percentage reduction of LF readings between initial and final measurements was statistically higher in the experimental group (Graph 2).

\section{DISCUSSION}

The LF device was introduced to diagnose carious lesions in occlusal and smooth surfaces. A diode laser emits a red light $(\lambda=655 \mathrm{~nm})$, which is absorbed by the dental tissues. Some of this light is re-emitted as near-infrared fluorescent light. With the progression of the carious process, there is an increase in the amount of fluorescent light. The system provides quantitative measurements of carious lesions $\mathbf{s}^{5,15,16}$.

Nevertheless, the molecules involved in the increase of fluorescence in carious tissues remain 
Mendes FM, Pinheiro SL, Bengtson AL. Effect of alteration in organic material of the occlusal caries on DIAGNOdent readings.

Braz Oral Res 2004;18(2):141-4.

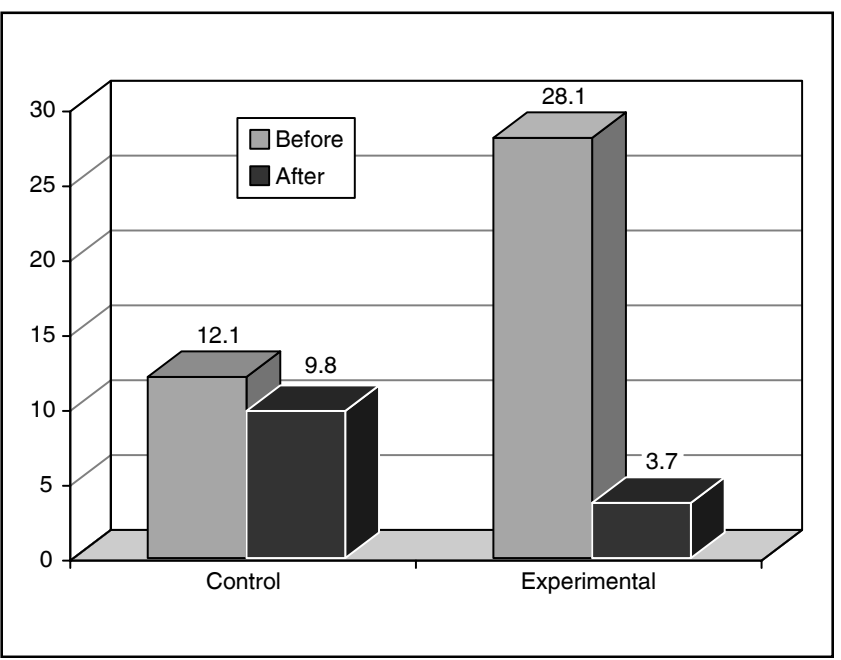

GRAPH 1 - Laser fluorescence readings of occlusal carious lesions from both control and experimental groups before and after immersion in the solutions (sodium hypochlorite in the experimental group and isotonic $\mathrm{NaCl}$ in the control group).

unclear ${ }^{15}$. While the QLF method detects intrinsic fluorescence from the mineral content of the teeth $^{18,20}$, the diode laser fluorescence was not able to detect in vitro remineralization in smooth-surface carious lesions in primary teeth ${ }^{11}$. Furthermore, QLF results have shown a better correlation with mineral loss in enamel carious lesions than LF measurements ${ }^{15}$.

Some researches have been carried out to clarify the LF mechanism. Little or no fluorescence was observed in synthetic hydroxyapatite with the LF device $^{5}$. A better correlation was achieved between LF readings and depth of lesions than that with mineral content of caries in smooth surfaces ${ }^{15,16}$.

The device reportedly does not measure small changes in mineral content adequately ${ }^{5,11,15,16,20}$. No fluorescence within the visible range was observed by illumination with a red laser light in sound enamel and in artificial enamel caries ${ }^{18}$. Besides, fluorescence changes were not observed in artificial carious lesions using the LF device ${ }^{5}$.

Probably, the LF readings reflect changes in the organic material rather than in the inorganic content of the teeth. Oral bacteria metabolites affect the signal ${ }^{5}$. In the present study, we observed a significant decrease in LF readings in occlusal caries after storage in sodium hypochlorite. Sodium hypochlorite is an effective agent that denatures organic components and does not change mineral content ${ }^{12}$.

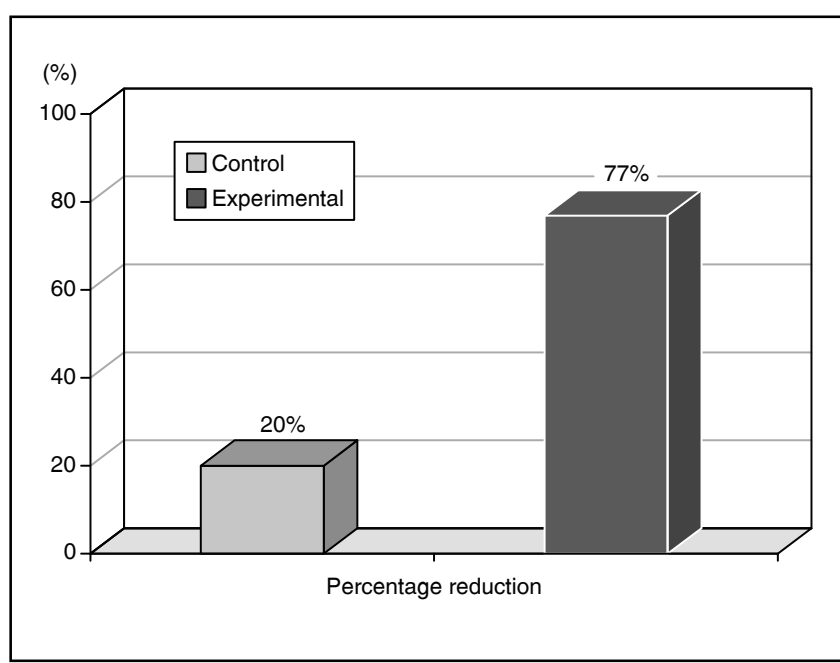

GRAPH 2 - Percentage reduction between laser fluorescence readings before and after immersion in the solutions in both control and experimental groups.

These results agree with the fact that an increase in the fluorescence is due to changes in the organic content of carious lesions rather than to the mineral disintegration. In another study, an increase in $L F$ readings was observed after storage of the teeth in $10 \%$ neutral-buffered formalin. An explanation for this result is that formalin denatures proteins ${ }^{16}$. In another study, a significant decrease was observed in $\mathrm{LF}$ readings after chemical irrigation with sodium hypochlorite and $\mathrm{H}_{2} \mathrm{O}_{2}{ }^{19}$. No alteration in measurements was observed after acid etching ${ }^{19}$. In our study, we also observed a decrease in LF measurements after storage in sodium hypochlorite.

In the present study, a statistically significant difference was observed between final and initial readings in both groups. However, this unexpected alteration in the control group is probably due to the wash with water coming from the 3 -in-1 syringe. Moreover, the difference in the control group was small (only three units, while the full capacity of $L F$ is up to $99^{16}$ ). In the experimental group, the difference was more significant (25 units). In fact, the percentage reduction observed in the experimental group was statistically higher than that in the control group.

Investigations have been accomplished to find what kind of molecules are responsible for the fluorescence increase with the use of the $655 \mathrm{~nm}$ diode laser. Bacterial colonies grown from carious swabs and their metabolites showed fluorescence 
Mendes FM, Pinheiro SL, Bengtson AL. Effect of alteration in organic material of the occlusal caries on DIAGNOdent readings.

Braz Oral Res 2004;18(2):141-4.

when excited by a $655 \mathrm{~nm}$ light ${ }^{5}$. The fluorescent molecules responsible for the increase of fluorescence in carious tissue seem to be porphyrins, mainly proto-porphyrin IX. These porphyrins could be synthesized by several microorganisms in carious lesions ${ }^{5-7}$.

There was a linear increase in the LF measurements with various amounts of proto-porphyrin IX. When these molecules were mixed with synthetic hydroxyapatite or dried on tooth surfaces, there was a marked increase in the DIAGNOdent readings ${ }^{5}$. However, further studies should investigate if other molecules contribute to the increase of fluorescence.

\section{REFERENCES}

1. Angmar-Mansson B, al-Khateeb S, Tranaeus S. Monitoring the caries process. Optical methods for clinical diagnosis and quantification of enamel caries. Eur J Oral Sci 1996;104:480-5.

2. Attrill DC, Ashley PF. Occlusal caries detection in primary teeth: a comparison of DIAGNOdent with conventional methods. Br Dent J 2001;190:440-3.

3. Bamzahim M, Shi XQ, Angmar-Mansson B. Occlusal caries detection and quantification by DIAGNOdent and Electronic Caries Monitor: in vitro comparison. Acta Odontol Scand 2002;60:360-4.

4. Bjelkhagen H, Sundstrom F, Angmar-Mansson B, Ryden $\mathrm{H}$. Early detection of enamel caries by the luminescence excited by visible laser light. Swed Dent J 1982;6:1-7.

5 . Hibst R, Paulus R, Lussi A. Detection of occlusal caries by laser fluorescence: basic and clinical investigations. Med Laser Appl 2001;16:205-13.

6. Konig K, Flemming G, Hibst R. Laser-induced autofluorescence spectroscopy of dental caries. Cell Mol Biol (Noisyle-grand) 1998;44:1293-300.

7. Konig K, Schneckenburger H, Hibst R. Time-gated in vivo autofluorescence imaging of dental caries. Cell Mol Biol (Noisy-le-grand) 1999;45:233-9.

8. Lussi A, Francescut P. Performance of conventional and new methods for the detection of occlusal caries in deciduous teeth. Caries Res 2003;37:2-7.

9. Lussi A, Imwinkelried S, Pitts N, Longbottom C, Reich E. Performance and reproducibility of a laser fluorescence system for detection of occlusal caries in vitro. Caries Res 1999;33:261-6.

10. Lussi A, Megert B, Longbottom C, Reich E, Francescut $P$. Clinical performance of a laser fluorescence device for detection of occlusal caries lesions. Eur J Oral Sci 2001;109:14-9.

11. Mendes FM, Nicolau J, Duarte DA. Evaluation of the effectiveness of laser fluorescence in monitoring in vitro

\section{CONCLUSION}

In conclusion, the present data indicate that changes in the fluorescence of carious lesions measured by the LF are mainly due to the organic content alterations rather than to the mineral loss occurred in dental caries.

\section{ACKNOWLEDGEMENTS}

The authors thank Mrs. Cintia Carla de Souza Pinheiro for the English corrections.

remineralization of incipient caries lesions in primary teeth. Caries Res 2003;37:442-4.

12. Robinson C, Hallsworth AS, Shore RC, Kirkham J. Effect of surface zone deproteinisation on the access of mineral ions into subsurface carious lesions of human enamel. Caries Res 1990;24:226-30.

13. Ross G. Caries diagnosis with the DIAGNOdent laser: a user's product evaluation. Ont Dent 1999;76:21-4.

14. Sheehy EC, Brailsford SR, Kidd EA, Beighton D, Zoitopoulos L. Comparison between visual examination and a laser fluorescence system for in vivo diagnosis of occlusal caries. Caries Res 2001;35:421-6.

15. Shi XQ, Tranaeus S, Angmar-Mansson B. Comparison of QLF and DIAGNOdent for quantification of smooth surface caries. Caries Res 2001;35:21-6.

16. Shi XQ, Tranaeus S, Angmar-Mansson B. Validation of DIAGNOdent for quantification of smooth-surface caries: an in vitro study. Acta Odontol Scand 2001;59:74-8.

17. Shi XQ, Welander U, Angmar-Mansson B. Occlusal caries detection with KaVo DIAGNOdent and radiography: an in vitro comparison. Caries Res 2000;34:151-8.

18. Sundstrom F, Fredriksson K, Montan S, HafstromBjorkman U, Strom J. Laser-induced fluorescence from sound and carious tooth substance: spectroscopic studies. Swed Dent J 1985;9:71-80.

19. Takamori K, Hokari N, Okumura Y, Watanabe S. Detection of occlusal caries under sealants by use of a laser fluorescence system. J Clin Laser Med Surg 2001;19:26771.

20. Tam LE, McComb D. Diagnosis of occlusal caries: Part II. Recent diagnostic technologies. J Can Dent Assoc 2001;67:459-63.

21.Zero DT. Dental caries process. Dent Clin North Am 1999;43:635-64. 